\title{
THE AUK:
}

\section{A QUARTERLY JOURNAL OF}

\section{ORNITHOLOGY.}

Vol. XXXIV. JANUARY, $1917 . \quad$ No. 1.

\section{DANIEL GIRAUD ELLIOT.}

BY FRANK M. CHAPMAN.

\section{Plate I.}

Daniel Giraud Elliot, A Founder of the American Ornithologists' Union, and its second President, died in New York City on December 22, 1915, in the eighty-first year of his age, from pneumonia after a short illness.

Dr. Elliot was born on March 7, 1835, in the city where he began and ended his career as a naturalist. He was the fourth son of George T. and Rebecca Giraud Elliot. His paternal ancestors were English and settled near New London, Connecticut, early in the 17th century. On his mother's side he was descended from French ancestors who settled at New Rochelle, New York, and moved to New York City some two centuries ago. He was married in 1858 to Ann Eliza Henderson, by whom he had two daughters, of whom but one, Margaret Henderson Elliot, is living.

Dr. Elliot prepared to enter Columbia College in 1852, but delicate health forced him to abandon a college course to seek climatic change. Thus was inaugurated a series of travels which either for the purposes of health, recreation, field exploration or museum research, led Dr. Elliot over a large part of the earth's surface.

The experience, specimens and data thereby acquired supplied the material on which his works were based, and we may begin our 
record of Dr. Elliot's life by a summary of the opportunities for study which his travels and museum affiliations afforded him.

His first journeys were made to the southern United States and West Indies. In 1857 he went to Rio Janeiro and on his return crossed to Europe travelling from Malta to Sicily and thence to the Nile. From Cairo he crossed the desert to Palestine visiting Petra, Bethlehem, Jerusalem and Damascus, and crossed the Lebanon Mountains at an altitude of 10,000 feet. Thence he returned to Europe and America. During this journey the museums of London and Paris were visited, and relations established which prepared the way for Dr. Elliot's later studies at these institutions.

These occupied the greater part of the period between 1869 and 1883. It was during the first part of this time that as the representative of the recently organized American Museum, Dr. Elliot secured important collections of birds for that institution.

In 1883 on resuming his residence in New York City, Dr. Elliot made his headquarters at the Museum to which he had rendered such important service, and soon began to prepare systematic papers on certain groups of birds from specimens in its much enlarged collections, now under the care of Doctor Allen. Acting on behalf of the Museum, with Jenness Richardson, its taxidermist, he made a trip in 1888 to Montana in search of Bison. No living specimens were seen, but much valuable osteologic material was secured.

In 1894 Dr. Elliot accepted a call from the trustees of the recently organized Field Museum to become the Curator of its Department of Zoölogy, and he occupied this post until his resignation in 1906. Two years after going to Chicago Dr. Elliot organized and led a Field Museum expedition into Somaliland. He was attacked by a serious illness before the expedition was completed, but large collections had already been made which subsequently were added to the study and exhibition collections of the Field Museum. The African mammals which form so attractive a feature of the exhibition halls of the Field Museum were secured by this expedition and subsequently mounted by Carl E. Akeley, who accompanied Dr. Elliot to Africa. Recognizing Akeley's exceptional talents as an animal sculptor, Dr. Elliot had previously secured his services for the Field Museum. 
The fact that Dr. Elliot was in his sixty-second year when he undertook this difficult African journey, and that he afterward made a collecting trip to the Olympic Mountains, is indicative of the energy and love of work which ever urged him from victory to fresh conquests.

His longest journeys, however, were made after he had resigned from the Field Museum and went in search of material on which to base his great monograph of the Primates. For this purpose he sailed for Europe in April, 1907, and remained abroad until 1909. After studying in all the principal museums of Europe he went to Egypt and to Ceylon, thence from Calcutta to Rangoon and passed through Burmah. Returning to Rangoon he went to the Straits Settlements and thence to Singapore. His route now led to Batavia in Java, and later to Hongkong, Canton and Shanghai. Then he journeyed 800 miles up the Yang-tse-Kiang to Hankow and from there he crossed to Peking and Tien-tsin, and back by sea to Shanghai. From China he went to Japan returning to New York through San Francisco.

Again taking up his quarters at the American Museum, which as a naturalist, in spite of his repeated absences, he always considered his real home, Dr. Elliot began to elaborate for his proposed monograph the enormous amount of data he had acquired in his travels.

The need for further study of the specimens in European collections arising, Dr. Elliot later revisited the museums of London, Paris, Leiden, Berlin, Dresden and Munich, before returning to New York to complete his monograph.

From this outline of Dr. Elliot's travels and researches in field and study, it will be observed that he had exceptional opportunities for the acquisition of the information embodied in the long list of publications which form so lasting and eloquent a record of his productive industry.

His first paper on birds, 'Descriptions of Six New Species of Birds,' was published in 'The Ibis' for October, 1859. Both the nature of the subject and the place of publication indicate that this paper was prepared during his first trip to Europe. It is evident moreover that this journey exerted a marked influence on the character of Dr. Elliot's ornithological studies which, following the European rather than American method, were monographic rather than regional in scope. 
For the succeeding ten years, however, his studies were largely made and his works published in America. Aside from shorter papers, these include a 'Monograph of the Tetraonidæ' (New York, 1864-1865), an imperial folio with twenty-seven hand-colored plates; a 'Monograph of the Pittidæ' (New York, 1867), an imperial folio with thirty-one colored plates. The new and heretofore unfigured species of the 'Birds of North America' (New York, 1866-1869), in two imperial folio volumes with seventy-two colored plates, and 'A Monograph of the Phasianidæ' (New York, 1872) also in two folio volumes with forty-eight colored plates.

With few exceptions the illustrations for these works were made by Dr. Elliot himself, and no expense was spared in their reproduction or in the setting of the text, and these monographs were the most elaborate publications of the kind which had appeared in this country.

Although the Monograph of the Pheasants was published in this country, the studies on which it is based were doubtless largely made abroad, and its preparation therefore opens the period of Dr. Elliot's long residence in Europe beginning in 1869, and covering most of the period to 1883 .

His work on the Pheasants was soon followed by 'A Monograph of the Paradiseidæ' (London, 1873), a folio with thirty-seven colored plates, and this in turn by a 'Monograph of the Bucerotidæ' (London, 1876-1882), a folio with fifty-nine colored plates; and 'A Monograph of the Felidæ (London, 1883), a folio with fortythree colored plates.

Recognizing his own limitations as an artist, Dr. Elliot secured drawings by Wolf and Keulemans for these later works, which attained to the high ideal set by the trained taste and excellent judgment of their author.

During this period many shorter papers were published in 'The Ibis,' 'Proceedings of the Zoological Society' and elsewhere, and in 1879 'A Classification and Synopsis of the Trochilidæ,' a quarto memoir of 300 pages, appeared as a "Smithsonian Contribution to Knowledge."

After returning to New York, the years between 1883 and 1894 were occupied in preparing the parts relating to the Gallinæ, Columbidæ and Trochilidæ for the Standard Natural History, a wholly 
new edition of the Pittidæ, reviews of several genera, and three handbooks on the Anatidæ, Limicolæ and Gallinæ of North America. As a sportsman Dr. Elliot had an extended field experience with the members of these families, much of which is contained in the biographical sections of these popular monographs.

The twelve years during which Dr. Elliot was connected with the Field Museum were the most fruitful of his life. His studies were now wholly devoted to mammals and despite the demands upon his time made by executive duties, and his expedition to Africa, he produced the following works of major importance: 'Synopsis of the Mammals of North America' (1 vol., 8vo, 1901); 'The Land and Sea Mammals of Middle America and the West Indies' (2 vols., 8vo, 1904); 'A Check-List of the Mammals of the North American Continent, the West Indies and Neighboring Seas' (1 vol., 8vo, 1905) and 'A Catalogue of the Collection of Mammals in the Field Columbian Museum (1 vol., 8vo, 1907). These were all published by the Field Museum.

The extended journeys made after his resignation from the Field Museum (1906) were as we have already seen productive of the great Monograph of the Primates. This was Dr. Elliot's last published work, and at the time of his death he was engaged in preparing an appendix to his 'Synopsis of the Mammals of North America.'

It was not, however, only through his published works that Dr. Elliot served the branches of science to which in the most literal sense of the expression, his life was devoted.

Fortunately for the institutions concerned, his was the guiding hand in laying the foundation of the Zoölogical Departments of two of the great museums of this country - the American Museum and the Field Museum. With a practical knowledge of the requirements of a working museum, Dr. Elliot was also a man of affairs who could impress the trustees of the institutions concerned with the soundness of his views. His services in acquiring collections of birds and mammals for the American Museum were of exceptional importance since, at the time, he was one of the few men, perhaps the only man in America qualified to give the advice needed. Recognizing his fitness, the trustees of that institution commissioned him to purchase material during a journey which, in the winter of $1868-69$, he was about to make to Europe. 
He therefore acquired the Maximilian of Wied collection, containing many types of South American species, the A. L. Heermann collection from the southwestern United States, and a large representative collection of the birds of the world, including a Great Auk, was purchased from the Parisian dealers, Verreaux Frères.

Dr. Elliot's own collection of about 1000 North American birds including four specimens of the Labrador Duck, a bird which he himself saw in the flesh in New York markets, had already been secured by the Museum; and he later (1888) presented to it the fine collection of Hummingbirds on which his 'Monograph' of this family was based; at the same time the Museum also came into possession of Dr. Elliot's valuable ornithological library containing many rare works of reference, and complete files of such indispensable magazines, as 'The Ibis' and 'Proceedings of the Zoological Society.'

Both abroad and at home Dr. Elliot's services to science were recognized by the bestowal of many honors. He was the first American to be elected a Member of the British Ornithologists' Union; he was a Fellow of the Zoological Society and served for years on its Publication Committee; he was also a Fellow of the Royal Society of Edinburgh, a Founder and Vice-president of the Zoölogical Society of France and the recipient of decorations from several European powers.

As already stated, Dr. Elliot was a Founder of the American Ornithologists' Union, and its President in 1890 and 1891, while the Nuttall Ornithological Club, Linnæan Society and New York Zoölogical Society elected him to honorary membership. In 1906 Columbia University conferred upon him the degree of Doctor of Science; in 1914 the Linnæan Society of New York presented him with its medal, and in 1915 he was elected a member of the Board of Trustees of the American Museum.

To this record of the more significant events and achievements in Dr. Elliot's career as a naturalist, which might be compiled by any biographer having access to the needed sources of information, the memorialist feels it to be his special duty to add some account of the man himself. Dr. Elliot was the last link connecting us with what Dr. Coues termed the Cassinian Period of American Ornithology - or the years between 1853 and 1858, When he 
began his studies of birds, Baird, Cassin, and Lawrence were the only working ornithologists in America. There were no bird-clubs, no A. O. U., no Museum of Natural History in the city in which he resided. There was, however, in New York at that time a taxidermist, John G. Bell, whom it will be remembered accompanied Audubon in 1843 on the Upper Missouri Expedition. Many of Dr. Elliot's specimens were preserved by Bell, to whom, indeed, was entrusted the task of mounting the Elliot collection after it had been acquired by the American Museum. It was the memorialist's privilege to know Bell during the latter years of his life. He was a man of marked personality and ardent enthusiasms, and it is more than probable that he was of assistance to young Elliot, not only in the preparation and identification of specimens, but that he also was influential in developing his inherent love for the study of birds.

In an address given before the Linnæan Society on March 24, 1914, acknowledging the receipt of the Society's Medal of Honor, Dr. Elliot himself presents us with an interesting sketch of the conditions under which he began his life-work:

"I do not suppose that my boyhood was different from that of any other lad who had been inoculated with the virus that was to strengthen and increase in power more and more with the passing years, until it should dominate and control his entire life. I began to make a collection of birds - why I began I have no idea, probably could not help it - and when it verged toward completion I did not know what to do with it, for there was no one of my age anywhere to be found who sympathized with me in my pursuit, or with whom I could rejoice upon the acquisition of some rare specimen; I was practically alone. My cousin Jacob Giraud, the author of the "Birds of Long Island," had just entered upon the close of his career, and wrote no more; Audubon, with decayed mental faculties had entered upon the last year of his life; DeKay had died in Albany, and in all the cities and within the boundaries of our great state there was but one working ornithologist, George Newbold Lawrence, a man greatly older than myself, whose sons were my friends and companions, but who had not inherited their father's scientific taste, and their interest in birds was simply that of shooting and eating them; a gastronomic fancy shared in by all the rest of the population.... In Massachusetts there were 
no ornithologists. Neither Allen nor Brewster had appeared, and their predecessor, Brewer, had hardly been heard from. Philadelphia was much better off. It had its Academy, collections and library, donated mainly by Dr. Wilson, and for its Curator of Ornithology, John Cassin, one of the most erudite and competent ornithologists this country has ever produced, and the only one of his time familiar with exotic forms. Leidy was at the height of his career, engaged upon the works which have brought him such a celebrated name. I worked a good deal in the old building, corner of Broad and Sansom Streets, my companion often having been Cope, then starting upon his career, and we used to labor at the same table, he with his alcoholic snakes and lizards, and I with my birds; and as I was shy of having my material brought in contact with his, he usually occupied the greater part of the table.

"With Cassin I was brought into rather intimate communication, because when I began to publish my monographs the plates were colored at the establishment of Bowen and Company, who served Audubon for so many years, and of which firm Cassin was then the head, and we were in constant correspondence as well as personal communication for a number of years. In Washington, Baird had only lately come to the Smithsonian Institution, and with that great patience for which he was noted and the methods of diplomacy which carried him so far in after years, he was feeling his way in his position as Assistant Secretary, not having much of the sympathy of his chief, Henry, who did not hesitate to declare that he would have sent all the specimens of mammals and birds out of the Institution if he had his way. There was no other naturalist then in Washington. Gill had just begun his study of fishes, but Ridgway or Coues had not yet peeped. In all the length and breadth of the land there was not a periodical devoted to the ways of birds, and it was hard sledging for a budding ornithologist."

Fortunately Dr. Elliot was so situated that he could give himself both time and opportunity to develop this obviously inborn taste. With the exception of his Curatorship in the Field Museum, he never held a paid position as a naturalist, and his pursuit of his researches at a time when studies of this kind were far from being encouraged, is an indication of the strength of the interest which never lost its fascination for him, 
His last task, the 'Monograph of the Primates,' was the greatest in size and most important in scientific value of any he had previously undertaken. While engaged in its preparation at the American Museum, he was one of the first of the scientific staff to reach his office, and with only a few minutes' pause for luncheon applied himself continuously to the monotonous labor of compiling synonymy and describing specimens. He seemed never to tire in either mind or body, but stuck persistently to whatever task he had in hand until it was completed. This ability to concentrate for many consecutive hours day after day, was one of Dr. Elliot's prominent characteristics, and goes far to account for the magnitude of his achievements. He was possessed of a phenomenal memory and could deliver verbatim an extended written paper without the aid of manuscript, or could recall with equal accuracy the exact language of an impromptu address. His eloquent tribute to Sclater and his associates delivered before the American Ornithologists' Union at its Congress in New York City, in 1913, was written, committed to memory and delivered without the aid of a note, and with the fluency and impressiveness which marked Dr. Elliot's public utterances.

Dr. Elliot was possessed of an exceptionally distinguished presence. Tall, and of fine figure, he carried himself with an easy erectness which never yielded to the weight of years. To strangers he appeared reserved, but this natural dignity of manner was merely the shield of a gentle, kindly, sympathetic nature, behind which one found a charming and congenial companion. His friendships, if slowly made, were enduring. Enemies, he had none, and even when his views differed radically from those held by others, I do not recall ever hearing him use a harsh or unjust word in criticism.

I was but an infant in ornithology when, in 1887, I first met Dr. Elliot at the American Museum; but our mutual interests soon bridged the gap separating us in knowledge as well as in years, and to my surprise I found that the courtly gentleman who at first had inspired in me no small degree of awe, was as funloving as a boy. Perhaps I may be permitted the relation of one personal incident, since it illustrates both Dr. Elliot's knowledge of a family of birds in which he was especially interested, as well as his consideration for the errors of his associates. 
In July, 1889, falling a victim to one of the jokes which native collectors sometimes unconsciously play on unsuspecting and inexperienced ornithologists, I described as new a Hummingbird from the Bogotá region. In acknowledging receipt of a copy of the description, Dr. Elliot, then absent from the Museum, mildly expressed his doubts as to the validity of the proposed new form, and on re-examination of the type and only known specimen, I found that it was composed of the head of one species and the body of another, so skilfully joined that it required close examination to detect the fraud.

A second paper was therefore written stating the true status of the alleged 'new species.' Before this confession of error was published, Dr. Elliot returned to the museum, and with a hope that he might possibly fall into the trap I had so unwittingly entered, I said nothing of my latest discovery and merely handed him the type of the 'new species' for examination. This was twenty-seven years ago, but I can still clearly see Dr. Elliot, after only a momentary examination of the specimen, looking at me over his glasses and hear him saying, with as much sympathy in his voice as though he himself had been responsible for the error, "See here my boy, there's something wrong." To his trained eye the fraud was as obvious as though I had shown him a Bluebird's body with a Cardinal's head. Nothing remained for me to do, therefore, but produce the manuscript of my confession with which I had taken the precaution to arm myself.

Dr. Elliot was in his seventy-eighth year when his great monograph of the Primates was completed. At this age most men, even those who have retained an exceptional measure of health and vigor, consider their life-work as ended. Few of their early associates remain and the days devoid of either duty or pleasure drag wearily along. But those who were privileged to know Dr. Elliot in these last years of his life never thought of him as old. Time, it is true, had left its visible marks, but his mind was as young, his interests as keen as those of men who could count but half his years. If the friends of his youth had gone, community of interests brought him new ones. Occupation never was wanting, for there were always fresh fields inviting conquest, and to the end he retained that joy in his work which is the priceless heritage of the born naturalist. 


\section{$2 \mathrm{BHL}$ Biodiversity Heritage Library}

Chapman, Frank M. 1917. "Daniel Giraud Elliot." The Auk 34, 1-10. https://doi.org/10.2307/4072535.

View This Item Online: https://www.biodiversitylibrary.org/item/54047

DOI: https://doi.org/10.2307/4072535

Permalink: https://www.biodiversitylibrary.org/partpdf/86534

\section{Holding Institution}

Smithsonian Libraries

\section{Sponsored by}

Smithsonian

\section{Copyright \& Reuse}

Copyright Status: Public domain. The BHL considers that this work is no longer under copyright protection.

This document was created from content at the Biodiversity Heritage Library, the world's largest open access digital library for biodiversity literature and archives. Visit BHL at https://www.biodiversitylibrary.org. 